\title{
Depression, Anxiety and Stress in Primary Health Care Users
}

\author{
João Luís Alves Apóstolo ${ }^{1}$ \\ Maria Henriqueta Figueiredo² \\ Aida Cruz Mendes ${ }^{3}$ \\ Manuel Alves Rodrigues ${ }^{4}$
}

Aim: Describe levels of depression, anxiety and stress among users of an urban/rural health centre, analyse sex differences and comorbidity between depression, anxiety and stress. Method: Descriptive co-relational study with a Portuguese version of DASS-21; consecutive sample $(n=343)$. Results: $40.52 \%, 43.48 \%$ and $45.06 \%$ of individuals present some degree of depression, anxiety and of stress, respectively. Severe or very severe levels of disturbance were found in $20.87 \%$ (anxiety), $22.38 \%$ (stress) and $12.24 \%$ (depression) of individuals. Women present higher levels of depression, anxiety and stress. Depression, Anxiety and Stress are strongly and positively associated. Conclusion: These results show high point prevalence - higher than in other countries - and reveal differences in sex as well as comorbidity. They may allow for the development of a local and community intervention strategy for mental health promotion and disease prevention, particularly for women.

Descriptors: Depressão; Ansiedade; Atenção Primária à Saúde.

\footnotetext{
${ }^{1}$ RN, Ph.D. in Nursing, Adjunct Professor, Escola Superior de Enfermagem de Coimbra, Portugal. Researcher, Unidade de Investigação em Ciências da Saúde, Domínio de Enfermagem, Coimbra, Portugal. E-mail: apostolo@esenfc.pt.

2 RN, Ph.D. in Nursing, Adjunct Professor, Escola Superior de Enfermagem do Porto, Unidade de Investigação da Escola Superior de Enfermagem do Porto, Portugal. E-mail: henriqueta@esenf.pt.

${ }^{3}$ RN, Ph.D. in Education; Coordinator Professor, Escola Superior de Enfermagem de Coimbra; Investigadora da Unidade de Investigação em Ciências da Saúde, Domínio de Enfermagem, Coimbra, Portugal. E-mail : mrodrigues@esenfc.pt.

${ }^{4}$ RN, Ph.D. in Education; Coordinator Professor, Escola Superior de Enfermagem de Coimbra, Portugal. Investigador, Unidade de Investigação em Ciências da Saúde, Domínio de Enfermagem, Coimbra, Portugal. E-mail: amendes@esenfc.pt.
}

Corresponding Author:

João Luis Alves Apóstolo

Unidade de Investigação em Ciências da Saúde. Domínio de Enfermagem

Av. Bissaya Barreto

Apartado 7001

CEP: 3046-851 Coimbra, Portugal

E-mail: apostolo@esenfc.pt 


\section{Depressão, ansiedade e estresse em usuários de cuidados primários de saúde}

Os objetivos deste estudo foram descrever níveis de depressão, ansiedade e estresse dos usuários de um centro de saúde urbano/rural, analisar diferenças de sexo e a comorbilidade entre depressão, ansiedade e estresse. Este é um estudo descritivo correlacional, aplicando-se uma versão portuguesa da DASS-21, em amostra consecutiva ( $n=343)$. Tem-se como resultados que 40,52, 43,48 e 45,06\% dos indivíduos apresentam, respetivamente, algum grau de depressão, ansiedade e estresse. Identificaram-se níveis graves ou muito graves de ansiedade em 20,87\% dos indivíduos, de estresse em $22,38 \%$ e de depressão em $12,24 \%$. As mulheres apresentam níveis médios de depressão, ansiedade e estresse mais elevados. Depressão, ansiedade e estresse estão forte e positivamente associados. Esses resultados apontam para elevada prevalência mais alta que em outros países - e revelam diferenças de sexo e comorbilidade. Com base neles, poder-se-á desenvolver estratégia de intervenção local e comunitária para a promoção da saúde mental e prevenção da doença, particularizando as mulheres.

Descritores: Depression; Anxiety; Primary Health Care.

\section{Depresión, ansiedad y estrés en usuarios de cuidados primarios de salud}

Los objetivos de este estudio fueron: describir niveles de depresión, ansiedad y estrés de los usuarios de un centro de salud urbana/rural, analizar diferencias de género y la comorbilidad entre depresión, ansiedad y estrés. Se trata de un estudio descriptivo correlacional aplicando una versión portuguesa de la DAS-21 en una muestra consecutiva $(n=343)$. Se constató algún grado de depresión, ansiedad y estrés en 40,52\%, 43,48\% y $45,06 \%$ de los individuos, respectivamente. Se identificaron niveles graves o muy graves de ansiedad en $20,87 \%$ de los individuos, de estrés en $22,38 \%$ y de depresión en $12,24 \%$. Las mujeres presentaron niveles promedios de depresión, ansiedad y de estrés más elevados. La depresión, la ansiedad y el estrés están fuertemente y positivamente asociados. Se concluye que estos resultados apuntan para una elevada prevalencia más alta que en otros países - y revelan diferencias de género y comorbilidad. Con base en los hallazgos, se podrá desarrollar una estrategia de intervención local y comunitaria para la promoción de la salud mental y prevención de la enfermedad, particularmente de las mujeres.

Descriptores: Depresión; Ansiedad; Atención Primaria de Salud.

\section{Background}

The impact of mental health problems is one of the main causes of morbidity in our societies, with subsequent limitations. It is estimated that, out of 870 million people living in Europe, about 100 million suffer from anxiety and depression. Depression is responsible for $6.2 \%$ of morbidity in the European region of the World Health Organization (WHO). The report from the WHO European Ministerial Conference ${ }^{(1)}$ analyses a study developed in England, in which the total costs of depression among adults were estimated at around
15.46 billion Euros in 2002 . These costs primarily result from loss of employment due to absenteeism and from premature mortality.

Therefore, the mental health area constitutes a public health priority, increasingly demanding earlier and more creative responses from health services, the involvement of primary care centres and an articulation between sectors ${ }^{(2-3)}$, in accordance with WHO guidelines. The management and treatment of mental disorders in primary care is a fundamental step to enable more 
people to get easier and faster access to services - we should recognize that many are already seeking this kind of help. This will provide for better care and reduce wastage due to unnecessary tests and inappropriate, non-specific treatments(4-5). If access to treatment becomes wider, indirect costs will be drastically reduced and direct costs will slightly increase. Only accurate diagnoses based on epidemiological studies can lead to correct interventions, reducing the weight of psychiatric disorders and the consumption of psychiatric medication, especially antidepressants ${ }^{(3,6)}$.

Mental disorders, especially depressive disorders, are common among Primary Health Care (PHC) users, but they may remain unrecognized and inadequately treated and there is no agreement as to the undetected morbidity rate ${ }^{(1,6-8)}$. Different filters occur before the patient has access to specialized health care and one of the most important is at the level of $\mathrm{PHC}^{(9)}$.

Health care providers may fail to recognize symptoms and follow the best practice recommendations because they may not have the time or resources to provide evidence-based treatment in primary care settings(4). Psychiatric symptoms are often disguised by somatic symptoms ${ }^{(10)}$. In primary care, somatic symptoms play an important role in the manifestation of depressive disorders ${ }^{(11)}$. Because this has been under-evaluated, clinical case review is not an adequate methodology to establish prevalence rates of mental disorders in these settings.

The lack of population-based epidemiological studies on the prevalence of mental disorders is well evidenced in literature, especially in Portugal. In the U.S.A., point prevalence estimates of between $4.8 \%$ and $8.6 \%$ have been reported ${ }^{(8,12)}$. A cross-cultural study ${ }^{(4)}$ in 15 cities from different countries, not including Portugal, presented the following prevalence of major psychiatric disorders in PHC: $10.4 \%$ for current depression, ranging from $2.6 \%$ to $29.5 \%$ and $7.9 \%$ for generalized anxiety, from $0.9 \%$ to $22.6 \%$.

A few disperse studies have presented results concerning the Portuguese context. A study conducted at a health center $(\mathrm{HC}), \mathrm{n}=927$, in $1989^{(13)}$, identified $50.9 \%$ of primary care patients with depression/ anxiety symptomatology. Another study developed in $2005^{(14)}(n=179)$ showed that $38 \%$ of women suffered from some kind of depressive disorder. It also revealed higher levels of depression in the age group of 45-54 and related a high education level to a lesser risk of depression, although only for women under 53. One other study ${ }^{(15)}$ that was recently developed at a small town's HC $(n=192)$ demonstrated that $50 \%$ to $62 \%$ of individuals showed "normal" or "mild" levels of stress, anxiety and depression, $16 \%$ to $21 \%$ "moderate" levels, and $20 \%$ to $29 \%$ "severe" or "extremely severe" levels.

The evidence shows a higher prevalence of depressive and anxiety disorders among women ${ }^{(16-18)}$, with a ratio between $1.5: 1$ and $2: 1^{(4)}$. In Portugal, there is little evidence of this tendency, although two recent studies suggest that women have a higher susceptibility. However, these studies are not consistent yet ${ }^{(15,19)}$.

Comorbidity between depression and anxiety is very important, implying severity of symptoms. In studies developed in Portugal, a strong correlation between depression, anxiety and stress was registered(15,20-21).

Despite the findings presented above, there are no previous population-based epidemiological studies that permit a solid evaluation of this public health problem in Portugal and a simple clinical case review is not a suitable methodology to establish the prevalence rates of depression(6).

In order to put in practice the foreseen noninstitutionalization policies ${ }^{(3-5)}$, the diagnosis of populations affective-emotional states, as well as an early detection of cases of illness in the community and the promotion of Mental Health emerge as relevant goals within the scope of PHC. Thus, this study aims to address existing shortcomings and contribute to a better understanding of this reality, thus promoting a higher response capacity of health services.

\section{Objectives}

To analyze the point prevalence of depression, anxiety and stress in patients at a health centre in a city in Northern Portugal; to analyze differences in sex and comorbidity between depression, anxiety and stress.

\section{Methods}

Type of study: Descriptive correlational study.

Procedures: After approval from the Ethics Committee of the respective Local Health Unit, the research project was formally approved by the Administration Board.

Once the participants had signed the declaration of informed consent, the questionnaires were selfadministered. In these questionnaires, they were asked to indicate to what extent each sentence could be applied to their experience in the previous days. Those who showed some kind of difficulty in filling out the questionnaires received help from research team 
members. Individuals were selected who attended appointments at the $\mathrm{HC}$ during the second week of December 2009, agreed to participate in the study voluntarily and were able to do so.

\section{Sample and Context}

This HC was chosen because it attended a population both rural and urban, therefore including the different characteristics of the Portuguese population. Patients enrolled in the HC: 41.0000. Sample size calculation: $\mathrm{n}=(\mathrm{pq} /$ error square $) \times 1.96$ square. Based on previous results $^{(15)}, \mathrm{p}=$ approximately $0.3 ; \mathrm{n}=331$.

$343 \mathrm{PHC}$ users participated in the study. Mean age: 43.82 years; SD=16.75; Minimum 18 years old; Maximum 99 years old; $72.89 \%$ were women and $27.11 \%$ men; $54.76 \%$ were married, $26.19 \%$ single, $11.01 \%$ divorced and $8.04 \%$ widowed. In relation to years of education, $29.61 \%$ had $4,28.10 \%$ between 5 and $9,24.47 \%$ between 10 and 12 , and $17.82 \%$ had a higher education degree.

Instrument: DASS-21, Portuguese version(20) - paper and pencil instrument, composed of socio-demographic and clinical questions (corresponding to the variables under study).

DASS-21 is a set of three four-point Likert subscales. Each subscale consists of seven items to assess depression, anxiety and stress disorders. Depression is characterized by low positive affectivity, reduced self-esteem and encouragement, and despair, whereas physiological hyperstimulation reveals anxiety (the DASS Anxiety scale corresponds most closely to the DSM IV symptom criteria for the various Anxiety Disorders, except for the Generalized Anxiety Disorder - GAD); stress is associated to persistent tension, irritability and a low threshold to become upset or frustrated(22). The DASS-21 Portuguese version has shown acceptable psychometric properties in a study with a clinical sample (strong reliability, criterion and construct validity), although the three-factor structure proposed by the original author of DASS is not clearly revealed, as the organization of anxiety and stress items is more adjusted to one single factor(20). Yet, in one other research developed with a non-clinical sample, factor analysis shows a structure of three factors, depression, anxiety and stress, similar to the original version, explaining $56.41 \%$ of total variance ${ }^{(21)}$.

DASS-21 scores were calculated for each subscale and multiplied by two. For each of the three states, the following classification was used: normal, mild, moderate, severe and very severe ${ }^{(22)}$.
In the sample under study, DASS-21 showed corrected correlation values of each item with the score in each subscale and with the overall score higher than 0.50 , and Cronbach's alpha coefficients of each subscale and overall between 0.82 and 0.94 .

Statistic measures

The statistic measures used in the study were: Mann-Whitney Test, Spearman's correlation, summary statistics, and absolute and percentage frequencies. The variables anxiety, depression and stress present high asymmetry, which is why we used non-parametric tests.

\section{Results}

As shown in Table 1 , in relation to the severity of individuals' affective-emotional states, $40.52 \%$ of individuals presented some degree of depression, with $12.24 \%$ revealing a severe or extremely severe level; $43.48 \%$ presented some degree of anxiety, with $20.87 \%$ revealing a severe or extremely severe level; $45.06 \%$ presented some degree of stress, with $22.28 \%$ revealing a severe or extremely severe level.

Table 1 - Severity of individuals' affective-emotional states $(n=343)$

\begin{tabular}{lccccc}
\hline Variables & Normal & Mild & Moderate & Severe & $\begin{array}{c}\text { Extremely } \\
\text { severe }\end{array}$ \\
\hline Depression & $59.48 \%$ & $11.08 \%$ & $17.20 \%$ & $6.12 \%$ & $6.12 \%$ \\
Anxiety & $56.52 \%$ & $6.67 \%$ & $15.94 \%$ & $7.25 \%$ & $13.62 \%$ \\
Stress & $54.94 \%$ & $11.92 \%$ & $10.76 \%$ & $13.08 \%$ & $9.30 \%$ \\
\hline
\end{tabular}

In relation to sex differences, women present higher levels of anxiety, depression and stress than men (Table 2).

Table 2 - Differences in individuals' affective-emotional states according to sex $(n=343)$

\begin{tabular}{llccccc}
\hline & Sex & $\mathbf{n}$ & Median & Mean Rank & $\mathbf{z}$ & $\mathbf{p}$ \\
\hline \multirow{2}{*}{ Depression } & Woman & 251 & 3.00 & 178.50 & -2.021 & 0.043 \\
& Man & 92 & 2.50 & 154.27 & & \\
Anxiety & Woman & 251 & 3.00 & 180.08 & -2.516 & 0.012 \\
& Man & 92 & 2.00 & 149.96 & & \\
Stress & Woman & 251 & 7.85 & 183.30 & -3.493 & 0.000 \\
& Man & 92 & 6.00 & 141.17 & & \\
\hline
\end{tabular}

There is a strong association between depression, anxiety and stress (Table 3). The intercorrelations between DASS-21 dimensions reveal high and positive values, varying between 0.72 and 0.74 . 
Table 3 - Matrix of correlations between the scores of each DASS-21 subscale $(n=343)$

\begin{tabular}{lcccccc}
\hline \multirow{2}{*}{ Dimensions of DASS } & \multicolumn{2}{c}{ Anxiety } & & \multicolumn{2}{c}{ Stress } \\
\cline { 2 - 3 } \cline { 5 - 6 } & rs & $\mathbf{p}$ & & rs & $\mathbf{p}$ \\
\hline Depression & 0.74 & 0.00 & & 0.72 & 0.00 \\
Anxiety & - & - & & 0.73 & 0.00 \\
\hline
\end{tabular}

\section{Discussion}

The results obtained for the point prevalence of affective-emotional disorders (depression, anxiety or stress) are similar to the ones found in other studies in Portugal ${ }^{(13-15)}$, but higher than the ones found in other countries $^{(4,8,12,23)}$. This difference in point prevalence might result from the fact that Portuguese samples usually have a higher proportion of women and studies appoint higher levels of affective-emotional disorders in women, as discussed ahead. The fact that the sample is mainly composed of women can constitute a study limitation. However, because the population of $\mathrm{PHC}$ users in Portugal is predominantly female, the data collection method in HCs usually suffers such bias.

Approximate values of anxiety and stress severity were found in a study with a Portuguese sample with similar characteristics(15). However, in relation to depression, those authors found higher values, with $20 \%$ of individuals showing severe and very severe levels of depression.

Sex differences are referred in several other non-Portuguese studies $(4,16-18,24)$. Portuguese studies, although not soundly consistent yet, point to a higher susceptibility of women to develop affective-emotional disorders. In a student-based study ${ }^{(19)}$, women registered higher levels of anxiety, stress and negative affectivity; in a study with primary care users(15), women reported higher levels of anxiety and depression, but there were no differences concerning stress.

The strong association between depression, anxiety and stress is also evidenced in this research, in line with previous results ${ }^{(15,20-21)}$. These authors discuss and compare their results, presenting arguments that sustain the belief that depression, anxiety and stress may be different points of the same continuum, alternative manifestations of a diathesis or even heterogeneous syndromes that are associated because they share some subtypes of symptoms. According to the tripartite model(25), anxious and depressed people share a basic structure: negative affectivity or general distress. These are responsible for the association between anxiety and depression measurements.

These results may account for the development of an early intervention strategy, at the local level and in the community, paying special attention to women. Such action serves the purpose of promoting Mental Health and preventing disease, as advocated by the WHO and National Plans for Health, entailing positive implications in terms of economy and health gains for the population ${ }^{(1-5)}$. Nevertheless, research on affectiveemotional disorders in PHC users should be continued, with representative samples from other regions in the country.

\section{Conclusion}

This study revealed that $40 \%$ to $45 \%$ of individuals present some degree of affective-emotional disorder. It should be stressed that around $20 \%$ present severe or very severe levels of anxiety and stress and that around $12 \%$ show severe or very severe levels of depression.

A sex difference was found, with women presenting higher levels of anxiety, depression and stress than men, and there was a high comorbidity between depression, anxiety and stress. These results are in accordance with the ones obtained in other samples, both national and international, regarding comorbidity and sex differences. As to the point prevalence of affectiveemotional disorders, our results globally agree with the ones obtained with Portuguese samples, and are higher than the ones registered in other countries.

\section{Acknowledgments}

To the undergraduate students of the Oporto Nursing School and to the nurses at the Matosinhos Health Centre who participated in the process of data collection. To Inês, grantee of UICISA-dE, for collaborating in the writing of this paper.

\section{References}

1. World Health Organization. Mental health: facing the challenges, building solutions: report from the WHO European Ministerial Conference [internet]. 2005. [acesso 23 ago 2007]. Disponível em: http://www.euro. who.int/document/E87301.pdf

2. Ministério da Saúde (PT). Direcção-Geral da Saúde. Plano nacional de saúde 2004-2010 [internet]. 2004. [acesso 10 nov 2006]. v. 2. Disponível em: http://www. dgsaude.min-saude.pt/pns/media/pns_vol2.pdf

3. Resolução do Conselho de Ministros n. 49/2008 (PT). Dispõe sobre o Plano Nacional de Saúde Mental (20072016). Diário da República I Série de 6 mar 2008. 
4. World Health Organization. The world health report 2001 - Mental Health: new understanding, new hope. Geneva: World Health Organization; 2001.

5. World Health Organization. The world health report 2008. Primary health care - now more than ever. Geneva: World Health Organization; 2008.

6. Gusmão RM, Xavier M, Heitor MJ, Bento A, Almeida JM. O peso das perturbações depressivas: aspectos epidemiológicos globais e necessidades de informação em Portugal. Acta Méd Port. 2005;18(2):129-46.

7. Wittchen HU, Kessler RC, Beesdo K, Krause P, Höfler M, Hoyer J. Generalized anxiety and depression in primary care: prevalence, recognition, and management. J Clin Psychiatry. 2002;63 Suppl 8:24-34.

8. MacMillan HL, Patterson CJS, Wathen CN, The Canadian Task Force on Preventive Health Care. Screening for depression in primary care: recommendation statement from the Canadian Task Force on Preventive Health Care. CMA] [internet]. 2005;172(1):33-5.

9. Goldberg D. Epidemiology of mental disorders in primary care settings. Epidemiol Rev. 1995;17(1):182-90.

10. Fabião C, Barbosa A, Fleming M, Silva C. Rastreio da perturbação de somatização nos cuidados primários de saúde. Resultados de um estudo piloto. Acta Méd Port. 2008;21(4):319-28.

11. Barkow K, Heun R, Ustün TB, Berger M, Bermejo I, Gaebel W, et al. Identification of somatic and anxiety symptoms which contribute to the detection of depression in primary health care. Eur Psychiatry. 2004;19(5):250-7.

12. Pignone MP, Gaynes BN, Rushton JL, Burchell CM, Orleans CT, Mulrow CD, et al. Screening for depression: recommendations from the U.S. Preventive Services Task Force. Ann Intern Med. 2002;136:765-76.

13. Resina $T$, Pinhão $A$, Neto $L$, Leitão $A$, Martins $J$, Augusto M. Depressão e ansiedade na consulta de clínica geral/médico de família. Acta Méd Port. 1989;2(1):7-10. 14. Gonçalves B, Fagulha T, Ferreira, A. A depressão nas mulheres de meia idade: estudo sobre as utentes dos cuidados de saúde primários. Psicologia. 2005;19:39-56. 15. Apóstolo J, Ventura A, Caetano C, Costa S. Depressão, ansiedade e stresse em utentes de cuidados de saúde primários (Depression, Anxiety and Stress in Primary Care Settings). Referência. 2008; Série 2(8):45-9.

16. Kornstein SG, Schatzberg AF, Thase ME, Yonkers KA, McCullough JP, Keitner GI, et al. Gender differences in chronic major and double depression. J Affect Disord. 2000;60(1):1-11.

17. Angst J, Gamma A, Gastpar M, Lépine JP, Mendlewicz J, Tylee A. Gender differences in depression. Eur Arch
Psychiatr Clin Neurosci. 2002;252(5):201-9.

18. Dew MA, Lynn MM, Hall M. Depression: epidemiology and risk factors. In: Potokar J, Thase ME. Advances in the management and treatment of depression [internet]. London: Taylor \& Francis; 2003. [acesso 29 out 2006]; p. 1-39. Disponível em: http://www.myilibrary.com/ Browse/open. asp?ID $=10437 \&$ loc $=9$

19. Apóstolo JLA, Rodrigues MA, Olvera JP. Evaluacion de los estados emocionales de estudiantes de enfermería. Index Enferm. 2007;56:26-9.

20. Apóstolo JLA, Mendes AC, Azeredo ZA. Adaptação para a língua portuguesa da Depression, Anxiety and Stress Scales (DASS). Rev. Latino-Am. Enfermagem. 2006;14(6):863-71.

21. Apóstolo JLA. O conforto pelas imagens mentais na depressão ansiedade e stresse. Coimbra: Imprensa da Universidade de Coimbra; 2010.

22. Lovibond SH, Lovibond PF. Manual for the depression anxiety stress scales. 2.ed. Sydney: Psychology Foundation; 1995.

23. Feliciano AB, Moraes SA. Demand for chronicdegenerative diseases among adults attended in a basic health unit at the city of São Carlos-SP. Rev. Latino-Am. Enfermagem. [internet]. 1999 [acesso 1 jun 2010];7(3):41-7. Disponível em: http://www. scielo.br/scielo.php?script $=$ sci_arttex\&pid $=$ S010411691999000300007\&lng=en. doi: 10.1590/S010411691999000300007

24. Jacques HAK, Mash EJ. A test of the tripartite model of anxiety and depression in elementary and high school boys and girls. J Abnorm Child Psychol. 2004;32(1):13-25.

25. Clark LA, Watson D. Tripartite model of anxiety and depression: psychometric evidence and taxonomic implications. J Abnorm Psychol. 1991;100(3):316-36. 